\title{
Assessing ecological land use and water demand of river systems: a case study in Luanhe River, North China
}

\author{
D. H. Yan ${ }^{1,2}$, G. Wang ${ }^{1,2}$, H. Wang ${ }^{1,2}$, and T. L. Qin ${ }^{1,2,3}$ \\ ${ }^{1}$ State Key Laboratory of Simulation and Regulation of Water Cycle in River Basin, China Institute of Water Resources and \\ Hydropower Research, Beijing, 100038, China \\ ${ }^{2}$ Water Resources Department, China Institute of Water Resources and Hydropower Research, Beijing, 100038, China \\ ${ }^{3}$ Environmental Science and Engineering Department, Donghua University, Shanghai, 201620, China
}

Correspondence to: G. Wang (hanhehebest@163.com)

Received: 16 August 2011 - Published in Hydrol. Earth Syst. Sci. Discuss.: 17 October 2011

Revised: 7 July 2012 - Accepted: 10 July 2012 - Published: 6 August 2012

\begin{abstract}
Economic and social development has greatly increased ecological water demand and modified land use of river systems worldwide, causing overall degradation of many of these systems. In this study, theoretical and technical frameworks for regionalization on the eco-environmental function of river systems are formulated and applied to the Luanhe River system. Based on its eco-environmental functions, this river can be regionalized into four types of firstclass functional areas: ecological preservation areas, habitat restoration areas, ecological buffer areas and development and utilization areas. Considering the overall ecoenvironmental functions, we assessed the ecological land use of the Luanhe River system. The total area of basic ecological land use is $876.98 \mathrm{~km}^{2}$; the restrictive ecological land use is $1745.52 \mathrm{~km}^{2}$; ecological land use of the river system returned from farmland is $284.25 \mathrm{~km}^{2}$; and that returned from construction land is $17.35 \mathrm{~km}^{2}$. The average minimum ecological flow of mainstreams in upper and middle reaches of the Luanhe River is $4.896 \mathrm{~m}^{3} \mathrm{~s}^{-1}$ based on the habitat method. And the recommended minimum and suitable annual ecological water demand of channels in the lower reaches are 391 million $\mathrm{m}^{3}$ and 819.5 million $\mathrm{m}^{3}$, respectively. The evaporation and seepage consumption and vegetation consumption in riparian zones of the Luanhe River system are approximately 132.6 million $\mathrm{m}^{3}$ and 145.3 million $\mathrm{m}^{3}$ per year, respectively. Our results suggest that is crucial to regulate the instream ecological water use of the Luanhe River's mainstream starting from the Panjiakou-Daheiting Reservoir system. We recommend accelerating ecological land-use
\end{abstract}

planning and strengthening the regulation of ecological water use on this river system focusing on important lower reaches under the condition of competitive water demand.

\section{Introduction}

Rivers are complex ecological systems consisting of river ecosystem and riparian ecosystem (Gregory et al., 1991). Rivers have a remarkable hydrological function, molding function and important eco-environmental functions, such as flood regulation and storage, groundwater recharge, sediment transport and salt discharge, pollutant diluting and biodiversity protection (Luo et al., 2004). In addition, rivers provide many social service functions, such as water supply, power generation, shipping, aquiculture and landscape entertainment (Liu and Liu, 2009). Because of the great number and importance of ecosystems and social services that rivers provide, they are subject to increasing exploitation and degradation. In recent centuries, an increasing amount of floodplain areas have been developed and utilized for agriculture, aquiculture and the development of cities and towns (Jones et al., 1999; Lytle and Merritt, 2004; Morgan et al., 2007). This has significantly changed the scale and pattern of ecological land use of river systems with an importance in safeguarding critical ecological processes and providing critical ecosystem services. The ecological water use of the river, which is essential for the conservation of native aquatic biodiversity and protection of natural ecosystem functions (Richter 
et al., 1997), is also seriously occupied. Consequently, the river system degrades under severe interference (Jones et al., 2010).

The earliest research on water demand of river ecological environment went back to the concern of US Fish and Wildlife Service (USFWS) about instream flow in the 1940s (Ward and Stanford, 1979). Between 1960s and 1970s, many scholars had discussed the methods for determining the minimum ecological instream flow, which were applied to the assessment and planning of some famous rivers (Loar and Sale, 1981). Between 1980s and 1990s, more sophisticated theoretical and methodological systems for the calculation of instream flow have been proposed (Bovee, 1986; Petts, 1996; Poff et al., 1997; Lytle and Poff, 2004; Henry and Amoros, 1995; Henry et al., 1995; Geoffrey, 1996; Hughes, 2001). Since 1980s, the restoration of degraded riparian ecosystems and the management of riparian buffer zones have received lots of concerns from regulatory agencies worldwide. A large number of experiments and research focusing on water resource protection, soil and water conservation and other basic eco-environmental functions of riparian buffer zones have been conducted (Lowrance et al., 1985; Knopf et al., 1988; Phillips, 1989; Sweeney et al., 2004; Schoonover et al., 2005; Baker et al., 2006; Lees and Peres, 2008; Lennox et al., 2011). Consequently, a number of new regulations regarding riparian management were created (Morrison, 1988; Welsch, 1991; Smith and Hellmund, 1993). Currently, the majority of resource development and eco-environmental protection research focus on microcosmic processes disregarding macroscopic aspects. Assessment on single functions (resource function or environmental function) is more frequently carried out than on multiple functions. Therefore, it is urgent to perform integrated management of river systems to maintain water and eco-environmental safety, so as to fully play the multi-attribute functions of the systems.

As one of the four first-class basins in Haihe River Basin, North China, Luanhe River Basin is not only an important mineral resource distribution area, but also one of the important water sources of Bohai Rim economic circle. With increasing economic and social development, the ecological land use and water use of the Luanhe River system have been seriously modified, which causes overall degradation of the river system and threatens the entire ecological and water safety of the basin. The objective of this study is to formulate suggestions for government policy makers in planning regional eco-hydrological regulation of the Luanhe River Basin. We take the Luanhe River as an example for our study in which we (1) assessed the ecological water demand of the river system, (2) presented and argued the theoretical and technical frameworks of regionalization on ecoenvironmental function of the river system, (3) regionalized the Luanhe River with systemic identification of crucial ecoenvironmental functional areas in the basin, and (4) evaluated the ecological land use in the Luanhe River system. We calculated the ecological instream flow including prototype observation experiments. This calculation was made using the habitat method, which is based on the theoretical framework of IFIM (instream flow incremental methodology). In this study, aquatic macroinvertebrates were taken as target species for instream flow evaluation, assuming that these species play an important role in sustaining the integrity of the aquatic ecosystem. Statistical methods are used in conjunction with GIS techniques and approaches in the ecological land-use assessment.

\section{Site description}

Located between $115^{\circ} 34^{\prime} \mathrm{E}-119^{\circ} 50^{\prime} \mathrm{E}$ and $39^{\circ} 02^{\prime} \mathrm{N}-$ $42^{\circ} 43^{\prime} \mathrm{N}$ in the northeast of North China Plain, the Luanhe River Basin covers a total area of $44700 \mathrm{~km}^{2}$ with an average width of $103 \mathrm{~km}$. Originating from the north foot of the Bayanguer Mountain in Zhangjiakou, Hebei Province, the river travels through 27 cities and counties of Hebei Province, Inner Mongolia autonomous region and Liaoning Province and finally flows into the Bohai Bay. The basin is inclined from northwest to southeast. The upper basin consists of Bashang and paddock plateau regions with undulating terrain and lots of wind deflation hollows. The middle basin consists of North Hebei and Yanshan Mountain hilly areas with very deep river valleys. The lower basin consists of Yanshan Mountain front plain and Luanhe delta plain, which are intensively influenced by human interference. The Luanhe River Basin shows diverse geomorphic types, of which mountains, hills and basins cover about $70 \%$ of the total basin area. Plateaus and plains account for about $16 \%$ and $12 \%$, respectively. In addition, river valleys, beaches, terrace and tableland are also broadly distributed in this area, where typical temperate continental climate prevails as hot and rainy in summer and cold and dry in winter. The mean annual temperature is $7.6^{\circ} \mathrm{C}$ and the mean annual rainfall is $520 \mathrm{~mm}$ with the rainy season from July to September. The river system is well developed in this basin, where nine first-class branch rivers exist with the catchment area more than $1000 \mathrm{~km}^{2}$. The location of the study area is shown in Fig. 1.

The Luanhe River has a large water volume in the Haihe River Basin. However, the development and utilization intensity of water resources in this basin is also continuously increasing with the fast growing water demand of the regional economy. Especially since the completion and operation of the Panjiakou Reservoir, Daheiting Reservoir and other large-scale major water conservancy projects in the mainstream of the Luanhe River, great changes have occurred to the flow and sediment processes of channels in the lower reaches due to dam regulation. This damages the physical structures of channels, causing the degeneration of river ecological functions and biodiversity loss, and also leads to the erosion and recession of the modern Luanhe River delta shore line. The ecological space of the river system 


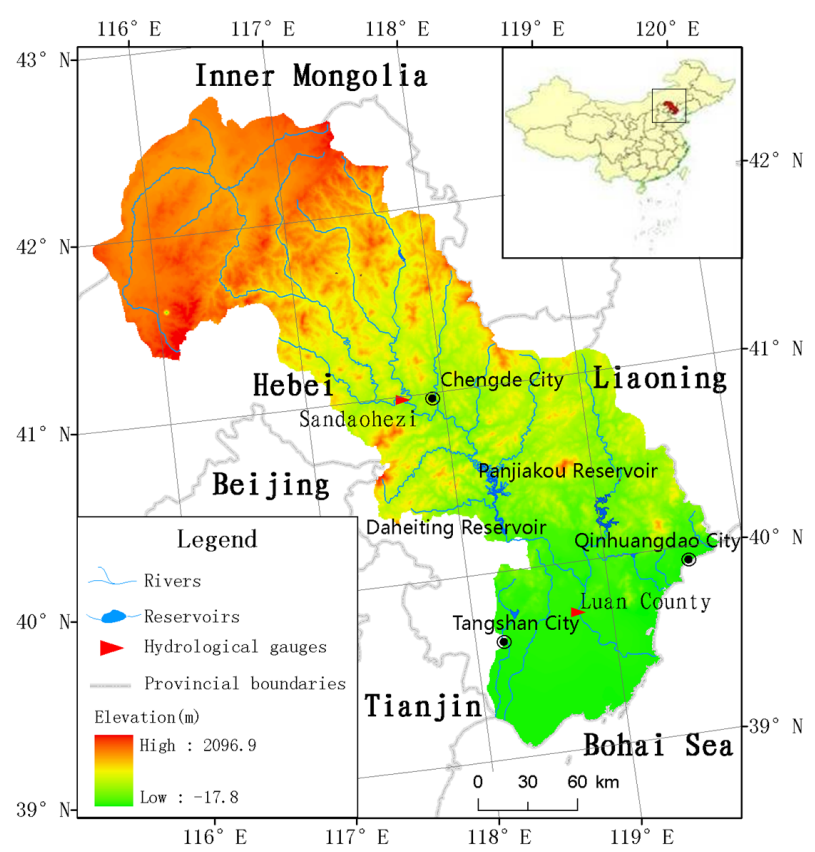

Fig. 1. Location of the study area.

is occupied by the unreasonable development and utilization of land resources in riparian zones, exacerbating the contradiction of the land struggle between human and water. With global climate change, the runoff of the Luanhe River system is dramatically decreased and the mean annual surface water resource during the period $2000-2009$ is only $40.6 \%$ of that between 1956 and 2000 according to the long-term observation data from gauging stations. In addition, emerging with the rapid development of economy, water quality problem causes the contradiction of water supply and demand even harsher.

\section{Materials and methods}

\subsection{Materials}

\subsubsection{Sampling}

Sampling of benthic invertebrates in the Luanhe River Basin was completed in July and October of 2010. Samples were collected in a series of sites from upper plateau reaches, middle mountainous reaches and lower plain reaches during different months under various flow conditions ( 21 sites in total, with a minimum of three samples per location). The locations of sampling sites in the Luanhe River Basin are shown in Fig. 2.

Firstly, study sections were divided into several areas according to habitat types of shallow, deep stream and deep pool for sample collection. The collection tools include a $30 \mathrm{~cm} \times 30 \mathrm{~cm}$ Surber sampler and a $15 \mathrm{~cm} \times 30 \mathrm{~cm}$ grab

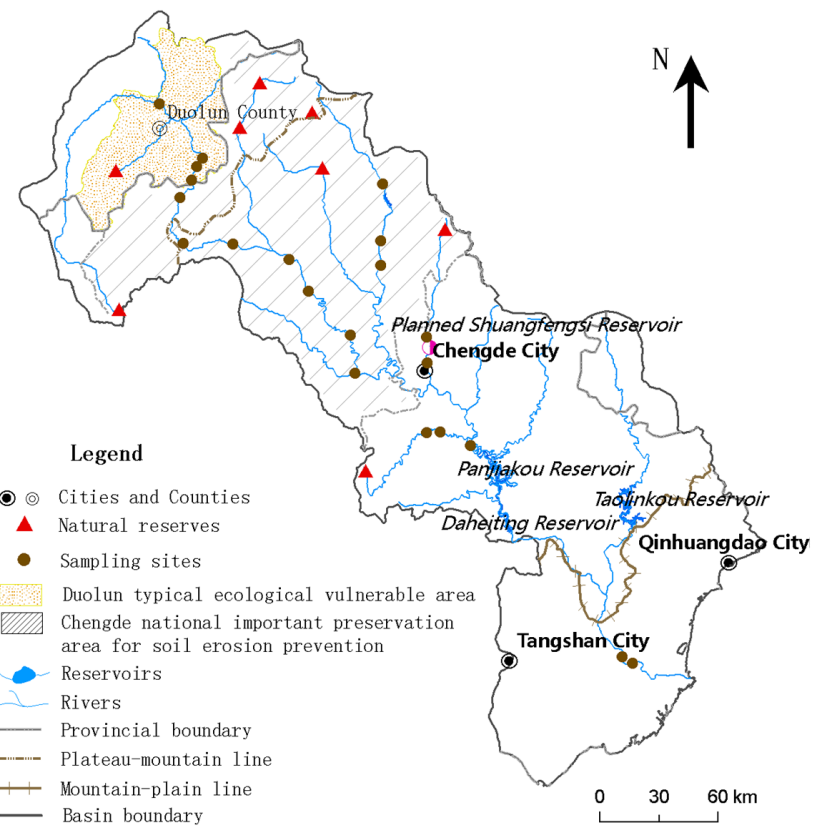

Fig. 2. Sampling sites and crucial eco-environmental functional areas in the Luanhe River Basin.

bucket-type sediment collector with primary collection areas of $0.09 \mathrm{~m}^{2}$ and $0.045 \mathrm{~m}^{2}$, respectively. The Surber sampler was applied to mountainous areas of the Luanhe River, where the substrate compositions of river beds are cobble or gravel with a water depth no more than $0.5 \mathrm{~m}$. Equipped with a $200 \mu \mathrm{m}$ stainless steel sieve, the grab bucket-type sediment collector had obvious advantages when applied to lower reaches with poor flowability and sand substrate in plain areas of the Luanhe River. The samples were fixed with $4 \%$ formaldehyde. Meanwhile, we recorded the measurements of water depth, mean water column velocity, water surface width and substrate characteristics of each sampling place. Moreover, the position of each sampling site was determined with GPS.

In the entire investigation, a total of 49 kinds of benthic animals were collected, belonging to 12 orders (classes) and 30 families. Among them, 36 kinds are aquatic insects, belonging to 7 orders and 21 families, accounting for $73.5 \%$ of the total. Five kinds are mollusks, belonging to 4 families and accounting for $10.2 \%$. Four kinds of oligochaeta belong to 2 families, accounting for $8.2 \%$. The remaining four kinds belong to 3 families, accounting for $8.2 \%$. Benthic animal communities, belonging to Chironomidae (Diptera), were identified at all sampling places with higher species abundance and dominance.

River systems in the upper, middle and lower reaches of the Luanhe River have distinct differentiation characteristics. Gradient changes with the order of rivers occur to geomorphology, soil, vegetation, land-use type and pattern of riparian zones, substrate composition of river beds, flow features 
and other properties of river banks, and the composition and distribution of instream biological groups. The descriptions of eco-environmental characteristics of sampling sites in different areas are listed in Table 1.

\subsubsection{Crucial eco-environmental functional areas}

Crucial eco-environmental functional areas mean those areas that have important ecological service function and play an important role in providing goods and services, safeguarding ecological integrity and biological diversity, and maintaining regional eco-environmental safety (Arcese and Sinclair, 1997; Marulli and Mallarach, 2005; Yu et al., 2004). At the same time, they are generally of high ecological sensibility and vulnerability (Long, 2001), and special attention should be given in the ecological land use planning and water management activities. The crucial eco-environmental functional areas in the Luanhe River Basin are shown in Fig. 2.

\section{Crucial natural preservation areas}

Lots of national and provincial natural reserves are distributed along the headstreams of some important branch rivers in the mountainous areas of the upper and middle reaches of the Luanhe River Basin. With an outstanding function of water source conservation, a large area of complete typical forest or prairie ecosystem is reserved in these preservation areas. Moreover, natural preservation areas possess abundant biological resources and gene pool resources with distinct and unique biological diversity. In addition, close to Beijing and Tianjin, these natural reserves play an important role in the protection of ecological safety of the BeijingTianjin area.

\section{Chengde important national soil erosion preservation areas}

The Luanhe River Basin in Chengde district is one of the 16 national important preservation areas in China approved by the State Council in 2006 for soil erosion prevention. The total area is $23000 \mathrm{~km}^{2}$, accounting for $80 \%$ of the catchment above the Panjiakou Reservoir, and this area is an important water source of the reservoir. Statistics showed that, during the period from 1990 to 2000, mean annual sedimentation of Panjiakou Reservoir was 12.61 million $\mathrm{m}^{3}$, triple over the period from 1980 to 1989 (Wang and Song, 2007). By the end of 2000, accumulated sedimentation of the reservoir was 180 million $\mathrm{m}^{3}$, accounting for $6.9 \%$ of the modified reservoir capacity. Although the protection of forests and vegetation has been strengthened in this area and the area of forestland and grassland has been greatly increased in recent years, the existing secondary forest still has poor soil and water retaining capacity and the ecosystems of forestland and grassland are vulnerable on the whole.

\section{Duolun typical ecological vulnerable area in the upper Luanhe River Basin}

The vulnerable area is located in Duolun County, Inner Mongolia autonomous region, where lots of low hills and sand dunes exist. Natural secondary forest, sand meadow and natural wetlands are sporadically scattered among sand belts. In this area, the annual rainfall is only about $380 \mathrm{~mm}$ and average wind velocity is $3.0-3.5 \mathrm{~m} \mathrm{~s}^{-1}$. As a transitional agropasture area, Duolun County has a vulnerable ecological environment with serious soil erosion problems. The soil erosion area reaches up to $3283 \mathrm{~km}^{2}$, accounting for $87 \%$ of the total, and a large quantity of sediment flows into the lower reaches of the Luanhe River every year. The aggravation of soil erosion and sandstorms not only plagues this county, but also threatens the environmental quality of the capital Beijing and the drinking water quality in Tianjin district.

\section{Water sources of major water supply and transfer projects}

Panjiakou Reservoir and Daheiting Reservoir exist as the water sources of water diversion projects from the Luanhe River to Tangshan and Tianjin cities. Taolinkou Reservoir is the water source of the Qing-Qin water transfer project, and Chengde Shuangfengsi Reservoir has been approved in this basin. With rapid economic development in upper reaches of the reservoir, total discharged industrial wastewater and urban domestic sewage have continuously increased in recent years, and the agricultural non-point source pollution has exacerbated by soil erosion. Moreover, water quality of the reservoirs has gradually degenerated with the development of mining industry around reservoirs in the upper reaches.

\subsection{Methods}

\subsubsection{Assessing ecological instream flow demand}

Among the body of techniques used to evaluate minimum flows, habitat method based on biological principles is regarded as a more reliable quantifying method at present. The method is principally based on the theoretical framework of instream flow incremental methodology (Midcontinent Ecological Science Center, 2001). In this study, the habitat method-WUW (Weighted Usable Width Method) is used to determine the minimum ecological instream flow.

The WUW method requires information on the preference for velocity, depth, substrate criteria and other important habitat factors of target species. And these suitability requirements can be defined by suitability curves of physical habitat parameters (Gore et al., 2001; Jowett and Richardson, 1990; Quinn and Hickey, 1990). Suitability curves are derived from a fit of some order polynomial to a plot of cumulative mean number of individuals of a taxon per sample as a function of an arbitrarily chosen increment of each physical habitat parameter (Gore and Judy, 1981; Gore et al., 2001). Substrate 
Table 1. Descriptions on eco-environmental characteristics of sampling sites in different areas.

\begin{tabular}{|c|c|c|c|c|c|}
\hline $\begin{array}{l}\text { Sampling } \\
\text { section area }\end{array}$ & $\begin{array}{l}\text { Structure of river bed and } \\
\text { river regime }\end{array}$ & $\begin{array}{l}\text { Substrate } \\
\text { composition }\end{array}$ & $\begin{array}{l}\text { Water surface } \\
\text { width }(\mathrm{m})\end{array}$ & $\begin{array}{l}\text { Water } \\
\text { depth }(m)\end{array}$ & $\begin{array}{l}\text { Flow } \\
\text { velocity }\left(\mathrm{m} \mathrm{s}^{-1}\right)\end{array}$ \\
\hline $\begin{array}{l}\text { Plateau area in the } \\
\text { upper reaches }\end{array}$ & $\begin{array}{l}\text { Sediment uplift type; } \\
\text { lots of shallows; drawer-shaped } \\
\text { section; wide and shallow; } \\
\text { high water quality }\end{array}$ & $\begin{array}{l}\text { Fine sand, } \\
\text { coarse sand }\end{array}$ & $10 \sim 40$ & $0 \sim 0.5$ & $0.1 \sim 0.4$ \\
\hline $\begin{array}{l}\text { Mountainous area } \\
\text { in the middle } \\
\text { reaches }\end{array}$ & $\begin{array}{l}\text { Lots of turns; irregular channels; } \\
\text { a large number of stagnant areas; } \\
\text { stable river bed structure with } \\
\text { ribwork or starry stones }\end{array}$ & $\begin{array}{l}\text { Cobble stone, } \\
\text { gravel and aquatic } \\
\text { plant }\end{array}$ & $10 \sim 30$ & $0.1 \sim 0.9$ & $0.1 \sim 1.0$ \\
\hline $\begin{array}{l}\text { Plain area in the } \\
\text { lower reaches }\end{array}$ & $\begin{array}{l}\text { Low slope; poor flowability; } \\
\text { serious sediment deposition; } \\
\text { hydrological regime greatly } \\
\text { affected by human activities; and } \\
\text { low water quality }\end{array}$ & Sludge and silt & $10 \sim 25$ & $0.3 \sim 0.7$ & $0 \sim 0.2$ \\
\hline
\end{tabular}

histograms can be plotted as the mean number of individuals of per substrate category and normalized to one, as described by Bovee (1986). Then, according to suitability curves, suitability indices $f(V)$ and $f(D)$ of each sampling sites are determined, which range from 0 to 1.0, indicating the surviving probability of target species under the corresponding habitat condition. For each habitat parameter, 0 indicates that the condition of the current habitat is completely not suitable for target species and 1.0 indicates the greatest suitability. Besides considering the influence of water quality on benthic animal, water quality suitability index $f(Q)$ was defined as $1.0,0.6$ and 0.3 , indicating clean, polluted intermediately and polluted seriously, respectively (Duan et al., 2011). Finally, the habitat suitability width of each section and each target species (i.e., WUW) was calculated with Eq. (1) (Karim et al., 1995):

$\mathrm{WUW}=\sum F\left[f\left(V_{i}\right), f\left(D_{i}\right), f\left(C_{i}\right), f\left(Q_{i}\right)\right] \times W_{i}$

where $W_{i}$ is the section width of $i$-th area in the study section; $f\left(V_{i}\right), f\left(D_{i}\right), f\left(C_{i}\right)$ and $f\left(Q_{i}\right)$ are the corresponding suitability indices of flow velocity, water depth, substrate composition and water quality, respectively; and $F$ [ ] is the combined habitat suitability factor, expressed as CSF, calculated with geometric mean method (Layher and Maughan, 1985):

$\mathrm{CSF}=\left(f\left(V_{i}\right) \times f\left(D_{i}\right) \times f\left(C_{i}\right) \times f\left(Q_{i}\right)\right)^{1 / 4}$.

Through establishing the relation curve between WUW and flow $Q$, the minimum flow can be finally obtained according to the determination of the breakpoint in the curve.

In all benthic animal communities, Diptera (especially Chironomidae), with the highest faunal diversity, were identified as the dominant species in sampling. Therefore, as target species, Chironomidae were used for constructing the habitat suitability model of benthic animals.

\subsubsection{Assessing evaporation and seepage of the river system}

In the surface evaporation of river water, evaporation depth of water body per unit area indicates evaporation capability. The following is the calculation equation on the net water demand of river evaporation consumption:

$W_{w}=\left(E_{w}-P\right) \times H \times L$

where $W_{w}$ is the net annual water demand $\left(\mathrm{m}^{3}\right)$ of surface evaporation consumption; $E_{w}$ is the actual annual evaporation capability $(\mathrm{mm}) ; P$ is the average annual rainfall $(\mathrm{mm})$ of a channel; $H$ is the average water surface width (m); $L$ is the river length $(\mathrm{km})$.

Since the water surface width of a river greatly changes with runoff within a year, water surface width in a normal flow period was used as the average width to calculate surface evaporation. The data of evaporation capacity and rainfall can be obtained from adjacent meteorological stations.

Water demand of channel seepage consumption can be calculated with the groundwater dynamic method and hydrological analysis method. However, it is difficult to obtain hydrogeological parameters related to these two methods in real calculation, and thus the water demand of seepage consumption was calculated roughly by multiplying the basic instream flow demand by a certain seepage rate. In reference to relevant research, the seepage rate of 0.15 was used for rough estimation (Wei et al., 2004).

\subsubsection{Assessing water demand of vegetation in riparian zones}

Water demand of vegetation in riparian zones can be simplified into water demands of forest land and grassland, calculated with the following equation:

$W_{p}=E_{p} \times A_{p}$ 
where $W_{p}$ is water demand of vegetation; $E_{p}$ is annual evaporation capacity of vegetation (mm); $A_{p}$ is the vegetation area in a riparian zone.

The physiological mechanism of water consumption by vegetation is very complicated, influenced by many factors, such as climate condition, vegetation condition and soil moisture condition. For convenience, the vegetation in riparian zone was classified into different vegetation types according to a general land utilization classification system and the value of $E_{p}$ for each vegetation type was obtained based on the relevant research results of the Haihe River Basin (Li et al., 2002). The coverage area of each vegetation type can be obtained from the land-use data from 2005.

\subsubsection{Eco-environmental functional regionalization of river systems}

\section{Connotation of functional regionalization}

River functional regionalization refers to a river regionalized into functional areas with different utilization types and different environmental quality requirements, according to location condition, resource condition, development and protection situations of various river reaches and regional requirements of economic and social development (Xu et al., 2009). Based on the definite functional properties of different reaches, corresponding control indices and limitation conditions are proposed for reasonably controlling and correctly guiding the utilization of rivers, so as to achieve the multidimensional purposes of environment improvement, landscape creation, ecological protection and sustainable utilization. Thereby, the contradiction between natural ecological functions and eco-social functions is well coordinated.

\section{Principles of functional regionalization}

The functional regionalization should be carried out on the basis of some guiding principles, which are of great importance for the integrity, reasonability and operability of regionalization results. These principles include respecting the natural attributes of rivers, meeting the habitat continuity among various functional areas, considering both the natural and social functions of rivers, giving prior to predominant functions and so on (Xu et al., 2009; Wu et al., 2011). The regionalization results should be consistent with water functional regionalization, which is particularly convenient for better protection and management of each functional zone. In addition, the regionalization should also be in line with the local socio-economic conditions to satisfy the reasonable water demands for economic development.

\section{Functional regionalization system}

There are lots of natural preservation areas in the upper reaches of the Luanhe River system with remarkable functions of water source conservation, protection of ecological integrity and biological diversity. Moreover, Luanhe River Basin is one of the areas with rapid economic development in North China, where many cities are built in river valleys with urbanization process accompanied by huge demands for water resources. Therefore, it is necessary to regionalize rivers into ecological preservation areas and development and utilization areas, in order to protect the natural integrity of river functions as well as meet reasonable water requirements of human activities. Aiming at grassland shrinkage and soil erosion in the upper and middle reaches, ecological function degradation in the plain channels of the lower reaches and other serious issues, ecological restoration and even reconstruction are required in some crucial reaches. Therefore, it is necessary to plan certain ecological restoration areas. Besides considering that administrative divisions enable rivers and reaches to be attached to different management entities, buffer areas or transitional areas should be established to ensure the functional integrality of the river corridor systems, so as to coordinate water demand contradiction among different management entities. Moreover, buffer areas should also be established among different functional areas. Thus, the firstclass eco-environmental functional regionalization system is required to include four types of areas: ecological preservation areas, habitat restoration areas, ecological buffer areas and development and utilization areas.

According to different water demand entities, development and utilization areas are further divided into secondclass functional areas, such as industrial water-use areas, agricultural water-use areas, drinking water source areas, aquiculture water-use areas, landscape water body areas and wastewater discharge control areas. With different protection objects, preservation areas can be further divided into natural preservation areas and water source preservation areas. The river eco-environmental functional regionalization system is shown in Fig. 3.

The following are the explanations on first-class ecoenvironmental functional areas:

\section{a. Ecological preservation areas}

Similar to the connotation of preservation areas in water functional areas ${ }^{1}$, ecological preservation areas refer to the areas crucial for water resource preservation, protection of natural eco-environment and rare or endangered species, in which all development activities are forbidden. The ecological preservation areas include headwater preservation areas, water source areas of national and provincial natural reserves or natural ecology systems with typical ecological protection value, and water source areas of large-scale trans-basin, trans-provincial and in-provincial water transfer projects.

\footnotetext{
${ }^{1}$ The Ministry of Water Resources of the People's Republic of China: Water functional regionalization of China, 2002.
} 


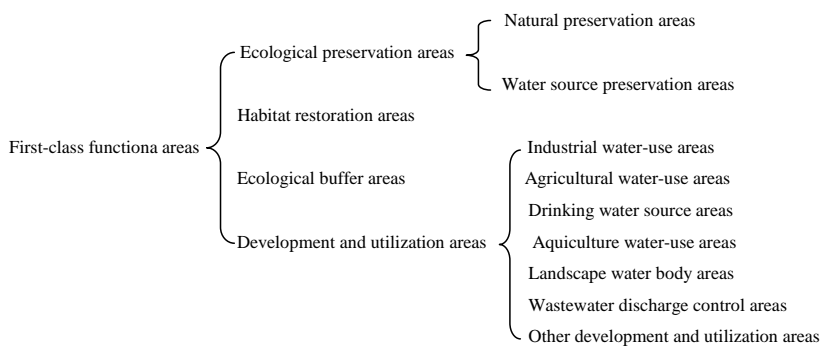

Fig. 3. Eco-environmental functional regionalization system of Luanhe River.

\section{b. Habitat restoration areas}

Habitat restoration areas refer to the areas where river ecosystems have been damaged to some extent by human interference, which can be restored to meet the requirements of continuity and functional integrity of stream habitats under the support of eco-social conditions and hydro-geographic conditions. During ecological restoration process, it is essential to exert human subjective initiative to restore existing damaged ecosystems, so as to improve and restore partial structures and functions of ecosystems and realize their selfmaintenance capabilities.

\section{c. Ecological buffer areas}

Ecological buffer areas are used for coordinating water demand issues among provinces and the areas with serious contradiction, in order to satisfy water requirements of various entities. When ecological preservation areas and habitat restoration areas are connected with development and utilization areas, ecological buffer areas can keep external influence away from ecological preservation areas, and connect broken habitats to realize structural integrity and functional continuity of river systems, thereby achieving the purposes of ecological buffering and social buffering.

d. Development and utilization areas

Same as the connotation of development and utilization areas in water functional areas, development and utilization areas mainly refer to the water areas able to meet the water demands of various sectors. These areas mainly consist of important urban reaches within the basin and the areas with extensive water intakes and large water demand on certain agricultural irrigation or fishery production.

\subsubsection{Assessment on ecological land use of Luanhe River}

The crucial issue for river ecological land-use assessment is to determine the scale and pattern of ecological land use. The desirable scale of ecological land use should be differentiated based on different eco-environmental functions in various reaches of this basin so as to ensure scientific and practicable regionalization results.

\section{Ecological land use of ecological preservation areas}

The river reaches with functions of water source conservation and drinking water source preservation are mostly located in the upper reaches of mountainous areas with a small population and low river development and utilization degree, where ecological land use can be determined with the method of planning buffer areas. In reference to surface water resource protection plan and regionalization results of urban centralized drinking water source in Hebei Province, the areas within $200 \mathrm{~m}$ on both river sides were designated as basic ecological land use. Strict protection measurements should be taken to forbid any form of development activities. The areas $1 \mathrm{~km}$ outside the envelope curves of basic ecological land use were designated as restrictive ecological land use, in which development activities could not affect the ecoenvironmental functions of buffer zones. An increasing area of ecological land use is required for reaches crossing over natural preservation areas to protect the integrity and continuity of habitats. The areas within $2 \mathrm{~km}$ on both river sides were designated as ecological land use in this study, and any form of developmental activities should be forbidden.

\section{Ecological land use of habitat restoration areas}

a. In the upper and middle reaches

The habitat restoration areas in the upper and middle reaches of the Luanhe River are mainly composed of two parts. One is the Duolun typical ecological vulnerable area, located in a transitional agro-pasture area with serious desertification and grassland degradation issues. The other is the Chengde important national soil erosion preservation areas with vulnerable forest and grassland ecosystems. Therefore, the riparian buffer zones with effective width are essential for controlling soil erosion. Research conducted by Copper et al. (1987) and Lowrance et al. (1988) showed that $80-100 \mathrm{~m}$ riparian buffer zones could effectively reduce $50-70 \%$ of sediments. Therefore, $100 \mathrm{~m}$ buffer areas on both river sides were designated as ecological land use in the habitat restoration areas.

b. In the lower plain reaches

Currently an improved flood prevention system including levees, mounds and bank protection works has been formed in the lower plain reaches of the Luanhe River. According to the land-use data from 2005, farmland accounts for $52.3 \%$ in the actual utilization of embankment areas, seriously occupying the ecological land use of the river system. Besides, since the operation of water 
conservancy projects has greatly reduced the instream flow, riparian zone with serious desertification problem accounts for $30.4 \%$ of embankment areas. Moreover, buildings and structures illegally established in channels are seriously affecting the flood discharge. The width of levees on both sides of the Luanhe River ranges from $2.5 \mathrm{~km}$ to $5.5 \mathrm{~km}$, while flood prevention mounds, spur dikes and other control and regulation works have been built within the levees. According to the flood control plan of the Luanhe River Basin, the flood control standard of mainstream is designed for resisting flood with a 50-yr reappearance period. Flood prevention mounds belong to beach flood discharge areas with short-term and long-term planning standards for resisting floods with 5-yr and 10-yr reappearance periods, respectively. According to the planning scheme of flood control and regulation approved by Department of Water Resources of Hebei Province, a regulation line with a total length of $75 \mathrm{~km}$ has been planned between Luanhe Jingshan railway bridge and the river estuary in the Luanhe River embankment area.

Complying with the principles of respecting actual situations and taking the priority of flood control, ecological land use was assessed within the embankment area, with the regulation line and the flood prevention mounds as boundaries, respectively. The area within flood prevention mounds was defined as the protection area of basic ecological land use, where enforced protection measures should be taken to forbid any form of development and occupation, so as to protect natural ecological landscape. Moreover, artificial flood pulses should be made effectively in high flow years to flood beach areas periodically, so as to gradually restore the basic eco-environmental functions of damaged channels. The area between flood prevention mounds and regulation lines was designated as restrictive development ecological land use. Appropriate agricultural activities are allowed in this area on the premise of no damage to flood discharge. The area between regulation lines and flood prevention levees was designated as ecological land use suitable for development, and people are encouraged to plant trees and undergo other activities to effectively manage and protect the flood prevention levees.

\section{Ecological land use of ecological buffer areas}

The functions of ecological buffer areas were defined between development and utilization areas and ecological preservation areas. It can be simply realized by designating certain buffer areas. The areas within $100 \mathrm{~m}$ on both river sides and areas $1 \mathrm{~km}$ outside the envelope curves were planned to be basic and restrictive ecological land use, respectively.

\section{Ecological land use of development and utilization areas}

Most of the development and utilization areas are located in cities, towns and other areas with high population density. The construction land use in riparian zones has formed in a certain scale and pattern; for example, the construction land in Chengde reach of the mainstream of Wuliehe River, a tributary of Luanhe River, accounts for $61 \%$ of the 100 yr floodplain area. And a certain land should be reserved and planned for future urban development. Therefore, the approach of designating a buffer area cannot be used for ecological land use assessment. Though the ecological land use of these areas is not rigidly restricted in our study, we suggest more emphasis on the protection of existing ecological land use and the regulation of ecological land use pattern.

The assessment criteria for different types of areas are generalized in Table 2.

\section{Results}

\subsection{Ecological water demand of the Luanhe River system}

\subsubsection{Minimum ecological instream water demand}

The suitability curves and substrate histograms are shown in Fig. 4. The flow velocity of the Luanhe River was measured between 0 and $0.97 \mathrm{~m} \mathrm{~s}^{-1}$. The suitability curve of flow velocity shows that the flow velocity suitable for Chironomidae is between $0.2-0.5 \mathrm{~m} \mathrm{~s}^{-1}$, and the most suitable flow velocity is about $0.3 \mathrm{~m} \mathrm{~s}^{-1}$. Some types of Chironomidae can also live in still water. When the flow velocity is higher than $0.6 \mathrm{~m} \mathrm{~s}^{-1}$, the suitability index declines greatly. When the flow velocity is higher than $1 \mathrm{~m} \mathrm{~s}^{-1}$, the species of Chironomidae, unresisting to water flow, have more difficulties surviving.

The water depths at sampling sites of the Luanhe River ranged from $0.03 \mathrm{~m}$ to $1.05 \mathrm{~m}$. The water depth suitable for Chironomidae is almost between $0.2 \mathrm{~m}$ and $0.4 \mathrm{~m}$, and the most suitable water depth is about $0.3 \mathrm{~m}$. Although some types of Chironomidae were identified in water areas above $0.7 \mathrm{~m}$, the diversity of species declined significantly.

The substrate composition of river beds at sampling sites was generally classified into seven types: fine sand, coarse sand, fluid mud, cobble, gravel, boulder and large aquatic plants. The influence of these sediment types on biomass and its density of Chironomidae shows that the favorite substrate type of Chironomidae benthic organisms is fluid mud, among which fluid mud river beds provide good nesting environment for burrowing type Chironomidae. When substrate changes into fine sand river beds, the diversity of Chironomidae benthic organisms sharply declines. As preferred substrate types of Chironomidae benthic organisms, cobble and gravel river bed can provide wide ecological habitat conditions. The biodiversity in boulder substrate is reduced 
Table 2. Summary of criteria of ecological land-use assessment for different types of functional areas.

\begin{tabular}{|c|c|c|c|c|c|}
\hline \multirow{2}{*}{\multicolumn{2}{|c|}{ Different types of functional areas }} & \multirow[b]{2}{*}{ Function orientation } & \multicolumn{3}{|c|}{ Assessing criteria } \\
\hline & & & $\begin{array}{l}\text { Basic ecological } \\
\text { land use }\end{array}$ & $\begin{array}{l}\text { Restrictive ecological } \\
\text { land use }\end{array}$ & $\begin{array}{l}\text { Ecological land use } \\
\text { suitable for } \\
\text { development }\end{array}$ \\
\hline \multirow[t]{2}{*}{$\begin{array}{l}\text { Ecological } \\
\text { preservation } \\
\text { areas }\end{array}$} & $\begin{array}{l}\text { Water source } \\
\text { areas }\end{array}$ & $\begin{array}{l}\text { Water source } \\
\text { conservation; water } \\
\text { source preservation }\end{array}$ & $\begin{array}{l}200 \mathrm{~m} \text { width range on } \\
\text { both river sides }\end{array}$ & $\begin{array}{l}1 \mathrm{~km} \text { outside the } \\
\text { envelope curves of } \\
\text { basic ecological } \\
\text { land use }\end{array}$ & - \\
\hline & $\begin{array}{l}\text { Natural } \\
\text { preservation } \\
\text { areas }\end{array}$ & $\begin{array}{l}\text { Ecological integrity } \\
\text { and biodiversity } \\
\text { protection }\end{array}$ & $\begin{array}{l}2 \mathrm{~km} \text { width range on } \\
\text { both river sides }\end{array}$ & - & - \\
\hline \multirow{2}{*}{$\begin{array}{l}\text { Habitat } \\
\text { restoration } \\
\text { areas }\end{array}$} & $\begin{array}{l}\text { Upper and } \\
\text { middle reaches }\end{array}$ & $\begin{array}{l}\text { Soil and water } \\
\text { conservation }\end{array}$ & $\begin{array}{l}100 \mathrm{~m} \text { width range on } \\
\text { both river sides }\end{array}$ & - & - \\
\hline & $\begin{array}{l}\text { Lower plain } \\
\text { reaches }\end{array}$ & $\begin{array}{l}\text { Flood prevention; } \\
\text { channel structural } \\
\text { integrity protection }\end{array}$ & $\begin{array}{l}\text { Area over the range } \\
\text { of flood prevention } \\
\text { mounds }\end{array}$ & $\begin{array}{l}\text { Area between flood } \\
\text { prevention mounds and } \\
\text { regulation lines }\end{array}$ & $\begin{array}{l}\text { Area between } \\
\text { regulation lines and } \\
\text { flood prevention levees }\end{array}$ \\
\hline $\begin{array}{l}\text { Ecological } \\
\text { buffer areas }\end{array}$ & & $\begin{array}{l}\text { Keeping functional } \\
\text { continuity of river } \\
\text { systems }\end{array}$ & $\begin{array}{l}100 \mathrm{~m} \text { width range on } \\
\text { both river sides }\end{array}$ & $\begin{array}{l}1 \mathrm{~km} \text { outside the } \\
\text { envelope curves of } \\
\text { basic ecological } \\
\text { land use }\end{array}$ & - \\
\hline $\begin{array}{l}\text { Development } \\
\text { and utilization } \\
\text { areas }\end{array}$ & & $\begin{array}{l}\text { Water supply for } \\
\text { various sectors }\end{array}$ & No rigid restriction & & \\
\hline
\end{tabular}

slightly, and the river bed substrate with submerged plant shows the lowest biodiversity.

The relationship between WUW of study sites and flow amount is shown in Fig. 5. Currently, slope and curvature methods are usually used for determining the critical minimum discharge, i.e., a breakpoint defined at the point of a specific slope (critical value 1 is taken generally) or the maximum curvature on WUW- $Q$ relation curve (Gippel and Stewardson, 1998; Shang, 2008). This breakpoint represents a critical discharge below which habitat conditions for aquatic organisms (usually fish or macroinvertebrates) rapidly become unfavorable. The breakpoint in the relationship was calculated using the slope method. The threshold flow of $4.896 \mathrm{~m}^{3} \mathrm{~s}^{-1}$ was obtained according to the fitting logarithmic function WUW $=4.896 \times \ln (Q)+11.04(p<0.001$, $\left.R^{2}=0.831\right)$. For comparison, we also calculated the average minimum monthly runoff of Sandaohezi, a typical hydrological station in the upper reaches of the Luanhe River. The value is $3.85 \mathrm{~m}^{3} \mathrm{~s}^{-1}, 21 \%$ smaller than the recommended value as being adequate for environmental protection. In addition, the recommended value is also within the range suggested in the literature ( $\mathrm{Ji}$ et al., 2010) using wetted perimeter approach to determine the minimum environmental flow.

With slow, even still flow, single river bed substrate and insignificant depth change gradient, the lower reaches of the Luanhe River are not suitable for establishing a suitable physical model of benthic animals. Besides, most of the study sites were intensively distributed in the upper and middle reaches of the river, where average minimum ecological flow of $4.896 \mathrm{~m} \mathrm{~s}^{-1}$ can be used as the minimum ecological instream flow of channels in the upper and middle reaches. In the research conducted by Wang et al. (2009), the minimum and suitable annual ecological water demand in the lower reaches of the Luanhe River was 429 million $\mathrm{m}^{3}$ and 893 million $\mathrm{m}^{3}$, calculated with monthly frequency method and ecological hydraulic method, respectively. In addition, the ecological water demand and controllable indices of the Haihe Basin have been studied in the special research on China regional ecological water demand standards, a project in the Tenth Five-Year National Science and Technology Breakthrough Plan. The minimum ecological water demand and suitable ecological water demand in the same river reaches were 353 million $\mathrm{m}^{3}$ and 746 million $\mathrm{m}^{3}$, respectively, calculated with the channel morphological analysis method. We used the average value of 391 million $\mathrm{m}^{3}$ and 819.5 million $\mathrm{m}^{3}$ in the above research as the minimum and suitable water demand of lower reaches of the river, respectively. 

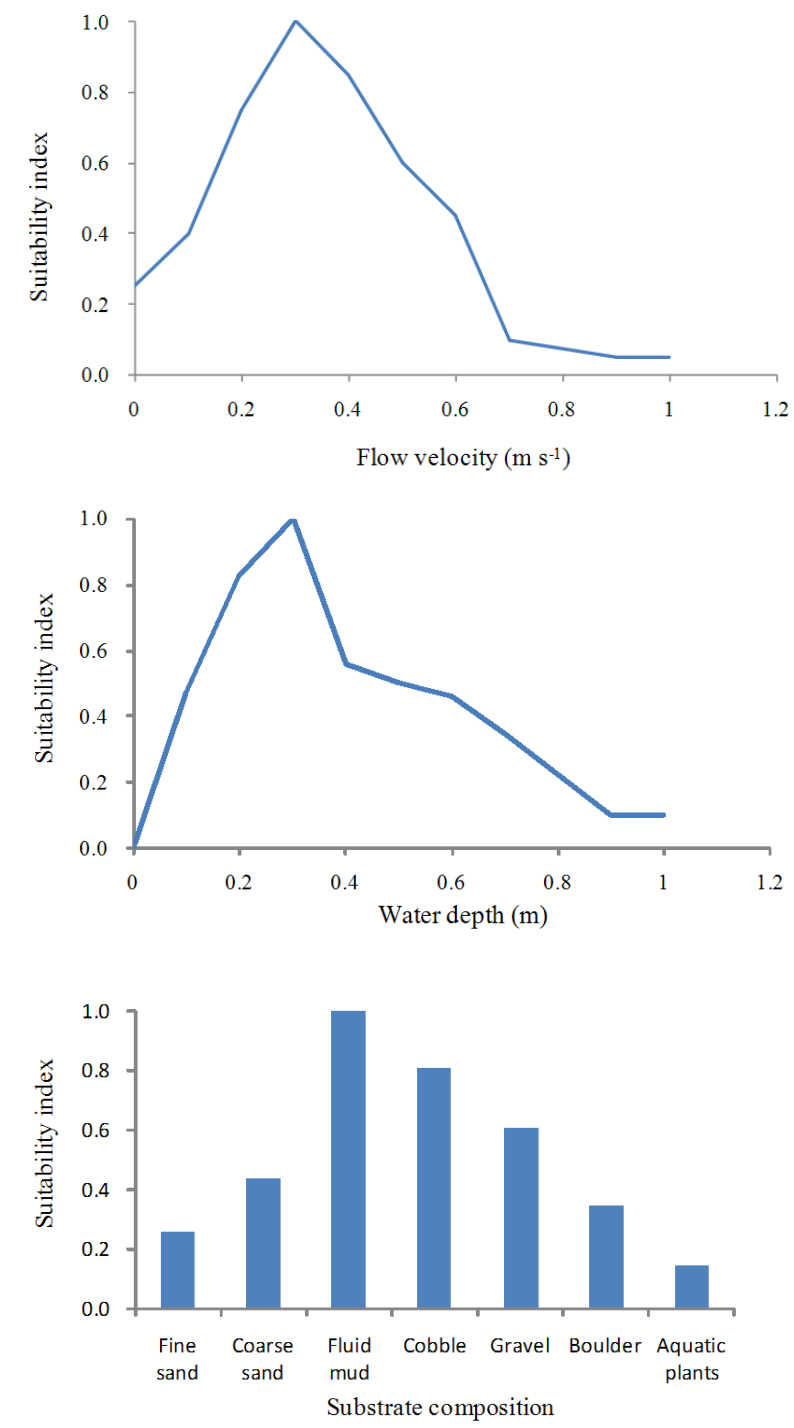

Fig. 4. Suitability model of Chironomidae (Diptera) to flow velocity, water depth and substrate composition.

\subsubsection{Evaporation, seepage and vegetation water demand of the river system}

Calculated with the method introduced in Sect. 3.2.2, 74 million $\mathrm{m}^{3}$ of water in the entire Luanhe River system are consumed by surface evaporation per year, and some detailed information is listed in Table 3. The annual channel seepage water consumption is 58.6 million $\mathrm{m}^{3}$, calculated by multiplying 391 million $\mathrm{m}^{3}$ by the seepage coefficient of 0.15 . The ecological water demand of vegetation in riparian zones is about 145.3 million $\mathrm{m}^{3}$ (Table 4), calculated with the method introduced in Sect. 3.2.3.

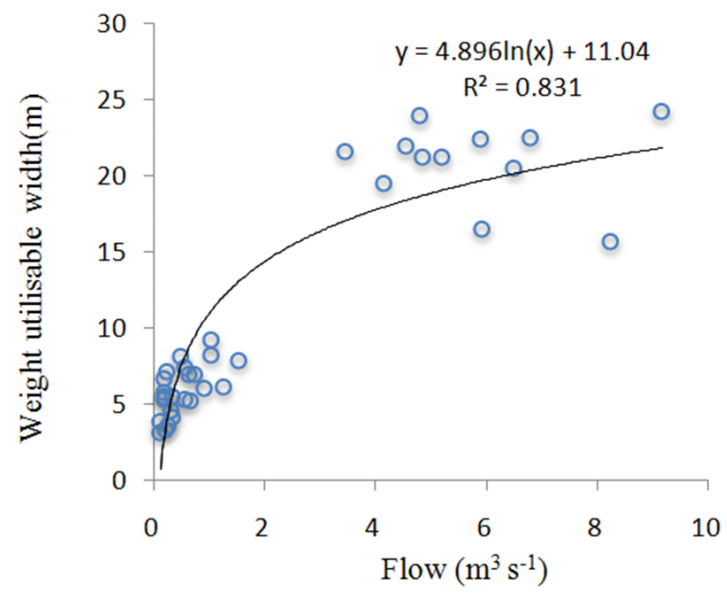

Fig. 5. Relationship between WUW and flow.

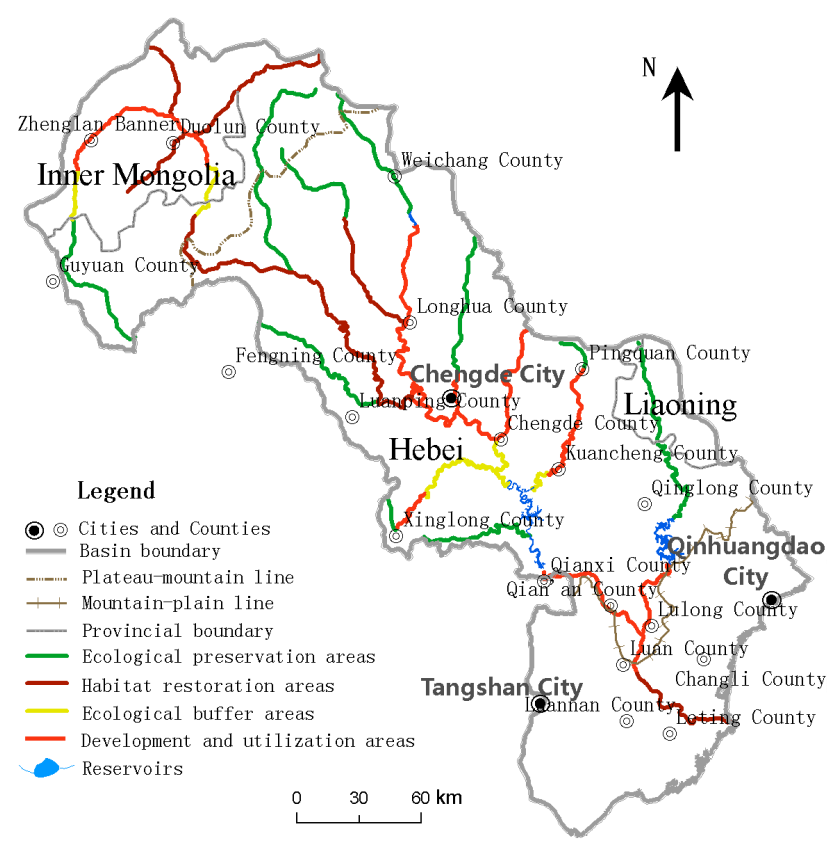

Fig. 6. First-class eco-environmental functional regionalization in Luanhe River.

\subsection{Eco-environmental functional areas of the Luanhe River}

The regionalization results on first-class eco-environmental functional areas of the Luanhe River are shown in Fig. 6. With the help of the geometry calculation tool of ArcGIS, the river length of each functional area can be easily obtained. We mainly focused on the Luanhe River system with a total length of $2099 \mathrm{~km}$ (reservoir areas are not included), disregarding the coastal rivers in the east of the Hebei Province in terms of the functional regionalization. Ten ecological preservation areas with a total river length of $728 \mathrm{~km}$ are 
Table 3. The statistics of water demand for surface evaporation in Luanhe River.

\begin{tabular}{lllllll}
\hline $\begin{array}{l}\text { Different river } \\
\text { reaches }\end{array}$ & $\begin{array}{l}\text { Average } \\
\text { water surface } \\
\text { width }(\mathrm{m})\end{array}$ & $\begin{array}{l}\text { Total river } \\
\text { length }(\mathrm{km})\end{array}$ & $\begin{array}{l}\text { Water surface } \\
\text { area }\left(\mathrm{km}^{2}\right)\end{array}$ & $\begin{array}{l}\text { Actual annual } \\
\text { evaporation } \\
\text { capability }(\mathrm{mm})\end{array}$ & $\begin{array}{l}\text { Average } \\
\text { annual } \\
\text { rainfall }(\mathrm{mm})\end{array}$ & $\begin{array}{l}\text { Water demand } \\
\text { for evaporation } \\
\left(\times 10^{8} \mathrm{~m}^{3}\right)\end{array}$ \\
\hline $\begin{array}{l}\text { Plateau area in the } \\
\text { upper reaches }\end{array}$ & 21.3 & 654.5 & 13.9 & 1650 & 430 & 0.17 \\
$\begin{array}{l}\text { Mountainous area in } \\
\text { the middle reaches } \\
\begin{array}{l}\text { Plain area in the } \\
\text { lower reaches }\end{array}\end{array}$ & 46.8 & 1354.3 & 63.4 & 1350 & 640 & 0.45 \\
\hline \begin{tabular}{l} 
Total \\
\hline
\end{tabular} & 103.6 & 160.7 & 1380 & 650 & 0.12 \\
\hline
\end{tabular}

Table 4. The coverage areas and values of water demand for each vegetation type in riparian zones of Luanhe River.

\begin{tabular}{llll}
\hline Vegetation type & Area $\left(\mathrm{km}^{2}\right)$ & $\begin{array}{l}\text { Water demand } \\
\text { per unit area } \\
\left(\mathrm{mm} \mathrm{yr}^{-1}\right)\end{array}$ & $\begin{array}{l}\text { Water demand for } \\
\text { each vegetation } \\
\text { type }\left(\times 10^{8} \mathrm{~m}^{3}\right)\end{array}$ \\
\hline Forest land & 67.19 & 500 & 0.336 \\
Bush & 83.10 & 330 & 0.274 \\
Open forest land & 10.36 & 330 & 0.034 \\
Other forest lands & 5.25 & 350 & 0.018 \\
Grassland with high coverage & 175.70 & 300 & 0.527 \\
Grassland with medium coverage & 115.99 & 210 & 0.244 \\
Grassland with low coverage & 12.86 & 150 & 0.019 \\
\hline Total & & & 1.453 \\
\hline
\end{tabular}

mainly distributed in the mountainous areas with significant importance in ecological preservation and water supply for downstream regions. Seven ecological restoration areas with a total river length of $533 \mathrm{~km}$ are mainly distributed in the upper and middle reaches of mountainous areas with serious soil erosion issues. And the lower reaches greatly influenced by dam regulation are also included in this type of functional areas. With a total river length of $649 \mathrm{~km}$, nine development and utilization areas are distributed in water areas close to cities and towns with large and intensive water demands. With a total river length of $189 \mathrm{~km}$, five ecological buffer areas are mainly distributed in the upper reaches of Hebei-Inner Mongolia provincial boundary areas and the inflow river reaches of Panjiakou Reservoir.

\subsection{Assessment on ecological land use of the Luanhe River}

According to criteria of ecological land use assessment for different types of functional areas introduced in Sect. 3.2.5, the ecological land use in ecological preservation areas, ecological buffer areas and habitat restoration areas of the Luanhe River was obtained and is shown in Fig. 7. The area of ecological land use for various functional areas was calculated with the help of geometry calculation tool in ArcGIS. The results are shown in Table 5. The areas of basic and restrictive ecological land use are $876.98 \mathrm{~km}^{2}$ and $1745.52 \mathrm{~km}^{2}$ in the Luanhe River system, respectively. In addition, ecological land use suitable for development with an area of $34.78 \mathrm{~km}^{2}$ was designated in the habitat restoration areas of plain channels in the lower reaches of the river. The areas of land required to be returned from farmland and construction land are $284.25 \mathrm{~km}^{2}$ and $17.35 \mathrm{~km}^{2}$, respectively. Among them, basic ecological land use of ecological preservation areas accounts for $76.3 \%$ with the maximum area of $669.36 \mathrm{~km}^{2}$. Therefore, the task on returning farmland and construction land is very tough.

\section{Discussion}

\subsection{Suitability of habitat suitability model}

Since the reproduction and growth of biological communities are characterized by periodicity, water demand of organisms in channels is not constant within a year (Thame, 2003; Lee et al., 2008). With limited sampling, the biological habitat physical model is mainly used for showing mean annual water demand characteristics of target species in our study. Therefore, it is necessary to carry out large-scale and highdensity prototype observation experiments in the next step, so as to provide support for constructing more detailed and 
Table 5. Ecological land-use assessment for different types of functional areas.

\begin{tabular}{lllll}
\hline $\begin{array}{l}\text { Functional } \\
\text { area type }\end{array}$ & $\begin{array}{l}\text { Basic ecological } \\
\text { land use }\left(\mathrm{km}^{2}\right)\end{array}$ & $\begin{array}{l}\text { Restrictive } \\
\text { ecological land use } \\
\left(\mathrm{km}^{2}\right)\end{array}$ & $\begin{array}{l}\text { Land required } \\
\text { to be returned from } \\
\text { farmland }\left(\mathrm{km}^{2}\right)\end{array}$ & $\begin{array}{l}\text { Land required } \\
\text { to be returned from } \\
\text { construction land }\left(\mathrm{km}^{2}\right)\end{array}$ \\
\hline $\begin{array}{l}\text { Ecological } \\
\text { preservation areas } \\
\text { Habitat } \\
\begin{array}{l}\text { restoration areas } \\
\text { Ecological } \\
\text { buffer areas }\end{array}\end{array}$ & 669.36 & 1271.15 & 212.31 & 13.49 \\
$\begin{array}{l}\text { Development and } \\
\text { utilization areas }\end{array}$ & -37.90 & 109.60 & 61.75 & 3.54 \\
\hline Total & 364.77 & 10.19 & 0.32 \\
\hline
\end{tabular}

accurate habitat models. In addition, aquatic species present great differentiation in community composition and distribution, which is determined by hydrological, ecological and environmental characteristics in different rivers. The habitat suitability model of Diptera with Chironomidae as the dominant species constructed in this paper is required to be further verified in other rivers.

\subsection{Rationality of river eco-environmental functional regionalization}

Generally, before the eco-environmental functional regionalization, a comprehensive assessment on the functions of river systems is required. Therefore, a set of index system needs to be established for evaluating crucial ecological functions quantitatively. This method is feasible for the research on a certain river reach. However, great difficulty is encountered in information collection in terms of a complex river system. Therefore, the crucial eco-environmental functional areas of this basin were only macroscopically identified. It is necessary to evaluate the hydrology, ecology and environment of rivers comprehensively in subsequent research, on the basis of massive prototype observation experiments, so as to optimize and improve the eco-environmental functional areas.

\subsection{Discussion on security regulation of ecological land use}

Aiming at the current intensive development and degradation issues of the Luanhe River system, basic ecological land use of this river was designated for protecting the critical ecological processes and maintaining the basic ecosystem services. The restrictive ecological land use serves as an important ecological barrier connecting basic ecological land use and human activity areas for alleviating the impact of human interference on the river system. This land-use type of the ecological preservation areas in the upper reaches is mainly used for blocking nutrient elements nitrogen and phosphorus to cut the pollution burden of water sources caused by agricultural non-point source pollution. The restrictive ecological land use of ecological buffer areas in inflow rivers of the Panjiakou Reservoir provides the similar function for ensuring water supply security. The main water demand entity of habitat restoration areas in plain channels along the lower reaches of the river is agricultural irrigation with a low requirement on the standard of water quality. Thus, restrictive ecological land use is mainly used for preventing the effect of the flood discharge capacity of channels. The ecological land use suitable for development is mainly used for encouraging people to actively participate in embankment maintenance and management.

A large area of land needs to be returned from farmland in the upper and middle reaches of Luanhe River Basin. These areas are usually underdeveloped in economy with a large agricultural population, and thus land is the main source of income for people. Therefore, in order to guarantee local residents' normal living standard and keep their enthusiasm on ecological land use protection, emphasis should be put on the issues of job placement and economic compensation. Although controllable indices are not required for farmland and construction land returning in the development and utilization areas along the middle and lower reaches of basin, ecological land use protection stress is actually transferred to the upper reaches. Therefore, the upper reaches should be compensated ecologically for fairness and coordination of the contradiction between upper and lower reaches.

\subsection{Discussion on security regulation of ecological water use}

The regulation of ecological water use mainly focuses on the basic ecological instream flow greatly influenced by human activities. Evaporation and seepage of river systems and water demand of vegetation in riparian zones are natural phenomena and difficult to be regulated. According to long-term observation data from the two typical hydrological gauges of Sandaohezi and Luan County, the runoff in the upper reaches of the Luanhe River with slight human interference 


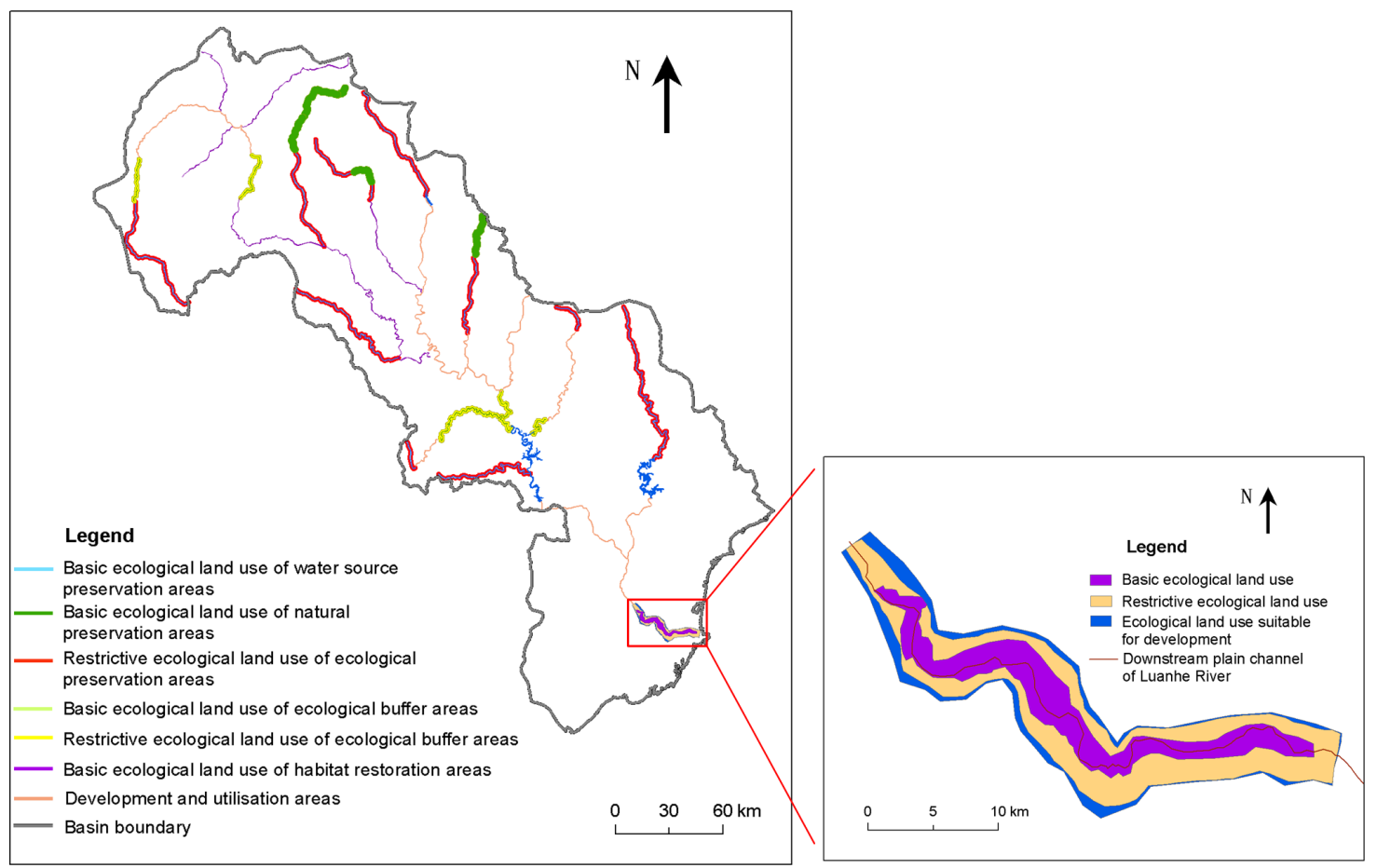

Fig. 7. Distribution of ecological land use in ecological preservation areas, ecological buffer areas and habitat restoration areas of Luanhe River.

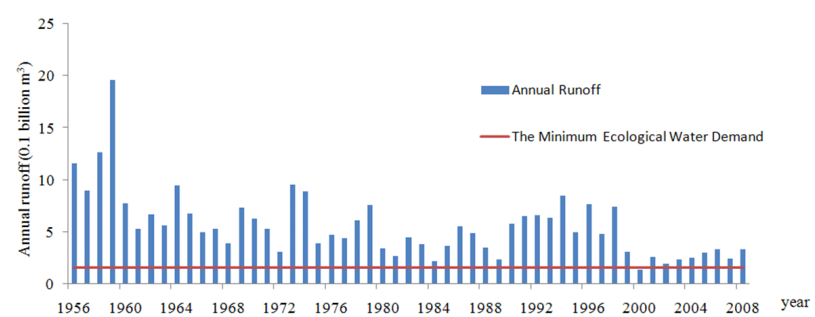

Fig. 8. Comparison between annual runoff and minimum ecological water demand of Sandaohezi Station in upper Luanhe River.

was not reduced as seriously as that of the lower ones, basically meeting the minimum ecological instream flow demand (see Fig. 8). The actual annual runoff of the Luan County Station during the period from 1956 to 2006 showed that the runoff of channels in the lower reaches could meet the suitable ecological water demand $\left(819.5\right.$ million $\left.\mathrm{m}^{3}\right)$ before 2000. However, with a gradual decrease in recent $10 \mathrm{yr}$, the runoff could not even satisfy the minimum ecological water demand (391 million $\mathrm{m}^{3}$ ) (see Fig. 9). Given the restoration of the ecosystem in the lower damaged reaches, the ecological water deficit of the river system would be bigger. Therefore, the reaches downwards from the Panjiakou Reservoir and the Daheiting Reservoir are important regulating areas. On the one hand, joint operation of existing multiple reservoir systems in this basin should be strengthened to strive for more ecological water use for channels in lower reaches through scientific management and allocation; on the other

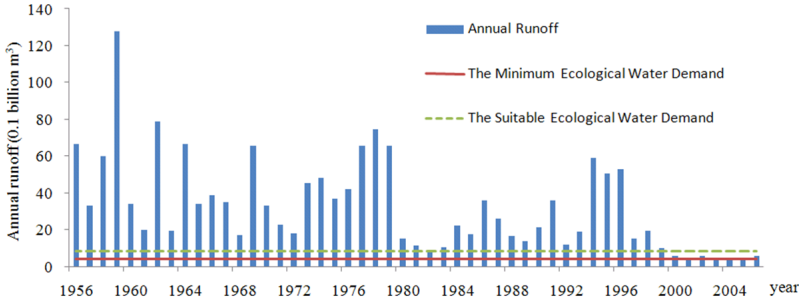

Fig. 9. Comparison between annual runoff and different levels on river ecological water demand at Luan County Station in lower reaches of Luanhe River.

hand, water sources transferred from other places should come into service, and industrial water and urban domestic water in the Tianjin area could be compensated effectively through the East Route Project of China's South-to-North Water Transfer, so as to replace part of the ecological water use for improving the ecological environment of channels.

\section{Conclusions}

Focusing on the main ecological and environmental problems as well as the requirements for the comprehensive ecological and hydrological regulation of rivers, we assessed ecological land use and water demand of the Luanhe River system and the following conclusions have been reached. 
The theoretical and technical framework on ecoenvironmental functional regionalization of river systems was proposed. Based on its crucial eco-environmental functions, the Luanhe River system was regionalized into four types of first-class functional areas, i.e., ecological preservation areas, habitat restoration areas, ecological buffer areas and development and utilization areas with river lengths of $728 \mathrm{~km}, 533 \mathrm{~km}, 189 \mathrm{~km}$ and $649 \mathrm{~km}$, respectively. The ecological preservation areas and development and utilization areas can be divided into several second-class functional areas according to the function orientation and actual demands.

The assessment on ecological land use of the Luanhe River system was performed on a basis of the eco-environmental functional regionalization in this river. The total area of basic ecological land use is $876.98 \mathrm{~km}^{2}$; the restrictive ecological land use is $1745.52 \mathrm{~km}^{2}$; ecological land use of the river system returned from farmland is $284.25 \mathrm{~km}^{2}$; and that returned from construction land is $17.35 \mathrm{~km}^{2}$. The area of basic ecological land use in ecological preservation areas is the maximum at $669.36 \mathrm{~km}^{2}$, accounting for $76.3 \%$ of the total; thus, the task for ecological land use regulation is very tough. Given the actual requirement of regional economic and social development, ecological land use in the development and utilization areas is not rigidly restricted, but the upper reaches of this basin should be compensated ecologically to some extent.

The ecological water-use demand of the river system was systemically calculated and analyzed according to water demand characteristics of ecological environment in the river system. Through constructing a large-scale physical model of the benthic invertebrate habitat, the average minimum ecological flow of mainstream in the upper and middle reaches of the Luanhe River was calculated at $4.896 \mathrm{~m}^{3} \mathrm{~s}^{-1}$, and the present instream flow basically meets the threshold value. The minimum ecological water demand is 391 million $\mathrm{m}^{3} \mathrm{a}^{-1}$ in the lower reaches of the Luanhe River, and the actual annual runoff in these reaches almost has failed to meet the recommended water demand since 2000. Therefore, the regulation on ecological water use of crucial reaches should be strengthened under the condition of competitive water demand. The annual water demand of evaporation and seepage consumption in the Luanhe River system is about 132.6 million $\mathrm{m}^{3}$, and water demand of the vegetation in riparian zones is about 145.3 million $\mathrm{m}^{3}$.

Acknowledgements. The authors would like to thank the the guest editor and two anonymous reviewers for their helpful comments, which improved the quality of the final manuscript. This study is jointly funded by climate change special fund (Grant No. 2010CB951102) and innovation research group foundation programme of Natural Science Foundation of China (Grant No. 51021066).

Edited by: A. Ghadouani

\section{References}

Arcese, P. and Sinclair, A. R. E.: The role of protected areas as ecological baselines, J. Wildlife Manage., 61, 587-602, 1997.

Baker, M. E., Weller, D. E., and Jordan, T. E.: Improved methods for quantifying potential nutrient interception by riparian buffers, Landscape Ecol., 21, 1327-1345, 2006.

Bovee, K. D.: Development and evaluation of habitat suitability criteria for use in the instream flow incremental methodology, Instream Flow Information Paper No. 21, US Fish and Wild life Service, Biological Report, Vol. 86, Washington, DC, 1986.

Copper, J. R., Gilliam, J. W., Daniels, R. B., and Robarge, W. P.: Riparian areas as filters for agricultural sediment, Soil Sci. Soc. Am. J., 51, 416-420, 1987.

Duan, X. H., Wang, Z. Y., and Xu, M. Z.: Zoobenthos and ecological assessment on rivers, Beijing, Tinghua University Press, 2011.

Geoffrey, E. P.: Water allocation to protect river ecosystems, Regul. River., 12, 353-365, 1996.

Gippel, C. J. and Stewardson, M. J.: Use of wetted perimeter in defining minimum environmental flows, Regul. River., 14, 5367, 1998.

Gore, J. A. and Judy Jr., R. D.: Predictive models of benthic macroinvertebrate density for use in instream flow studies and regulated flow management, Can. J. Fish. Aquat. Sci., 38, 13631370, 1981.

Gore, J. A., Layzer, J. B., and Mead, J.: Macroinvertebrate instream flow studies after 20 years: A role in stream management and restoration, Regul. River., 17, 527-542, 2001.

Gregory, S. V., Swanson, F. J., Mckee, W. A., and Cummins, K. W.: An ecosystem perspective of riparian zones, Bioscience, 41, 540-551, 1991.

Henry, C. P. and Amoros, C.: Restoration ecology of riverine wetlands: I. A scientific base, Environ. Manage., 19, 891-902, 1995.

Henry, C. P., Amoros, C., and Giuliani, Y.: Restoration ecology of riverine wetlands: II. An example in a former channel of the Rhone River, Environ. Manage., 19, 903-913, 1995.

Hughes, D. A.: Providing hydrological information and data analysis tools for the determination of ecological instream flow requirements for South African rivers, J. Hydrol., 241, 140-151, 2001.

Ji, L. N., Liu, S. X., and Wang, X. C.: Wetted perimeter approach to estimate instream flow requirements: a case study in Luanhe water system, Res. Geogr., 29, 287-291, 2010 (in Chinese).

Jones III, E. B., Helfman, G. S., Harper, J. O., and Bolstad, P. V.: Effects of riparian forest removal on fish assemblages in southern Applachian streams, Conserv. Biol., 13, 1454-1465, 1999.

Jones, K. B., Slonecker, E. T., Nash, M. S., Neale, A. C.,Wade, T. G., and Hamann, S.: Riparian habitat changes across the continental United States (1972-2003) and potential implications for sustaining ecosystem services, Landscape Ecol., 25, 1261-1275, 2010.

Jowett, I. G. and Richardson, J. Y.: Microhabitats of benthic invertebrates in a New Zealand river and the development of instream flow habitat models for Deleatidium spp., New Zeal. J. Mar. Fresh., 24, 19-30, 1990.

Karim, K., Gubbels, M. E., and Goulter, I. C.: Review of determination of instream flow requirements with special application to Australia, J. Am. Water Resour. As., 31, 1063-1077, 1995. 
Knopf, F. L., Johnson, R. R., Rich, T., Samson, F. B., and Szaro, R. C.: Conservation of riparian ecosystems in the United States, Wilson Bull., 100, 272-284, 1988.

Layher, W. G. and Maughan, O. E.: Spotted bass habitat evaluation using an unweighted geometric mean to determine HSI values, Proc. Okla. Acad. Sci., 65, 11-17, 1985.

Lee, F. Q., Cai, Q. H., Fu, X. C., and Liu, J. K.: Suitability model construction on habitation of stream macrozoobenthos and research on instream environmental flow - taking Xiangxi River in Three Gorges Reservoir area as the example, Nat. Sci. Prog., 18, 1417-1424, 2008 (in Chinese).

Lees, A. C. and Peres, C. A.: Conservation value of remnant riparian forests corridors of varying quality for Amazonian birds and mammals, Conserv. Biol., 22, 439-449, 2008.

Lennox, M. S., Lewis, D. J., Jackson, R. D., Harper, J., Larson, S., and Tate, K. W.: Development of vegetation and aquatic habitat in restored riparian sites of California's north coast rangelands, Restor. Ecol., 19, 225-233, 2011.

Li, L. J., Li, H. B., and Wang, J.: Study on ecological water requirements outside riverways in Haihe River Basin, Haihe Water Resour., 4, 9-12, 16, 2002 (in Chinese).

Liu, C. M. and Liu, X. Y.: Healthy river and its indication, criteria and standards, J. Geogr. Sci., 19, 3-11, 2009.

Loar, J. M. and Sale, M. J.: Analysis of environmental issues related to small-scale hydroelectric development, Oak Ridge National Laboratory, Oak Ridge, 1981.

Long, H. L.: Construction and forecast impacts of special ecological functional area in headwater of Yellow River, Territory \& Natural Resources Study, 1, 44-47, 2001 (in Chinese).

Lowrance, R., Leonard, R., and Sheridan, J.: Managing riparian ecosystems to control nonpoint pollution, J. Soil Water Conserv., 40, 87-91, 1985.

Lowrance, R., McIntyre, S., and Lance, C.: Erosion and deposition in a field/forest system estimated using cesium-137 activity, J. Soil Water Conserv., 43, 195-199, 1988.

Luo, H. M., Li, T. H., Ni, J. R., and Wang, Y. D.: Water demand for ecosystem protection in rivers with hyper-concentrated sediment-laden flow, Supplement 1, Sci. China Ser. E, 47, 186198, 2004.

Lytle, D. A. and Merritt, D. M.: Hydrologic regimes and riparian forests: a structured population model for cottonwood, Ecology, 85, 2493-2503, 2004.

Lytle, D. A. and Poff, N. L.: Adaptation to natural flow regimes, Trends Ecol. Evol., 19, 94-100, 2004.

Marulli, J. and Mallarach, J. M.: A GIS methodology for assessing ecological connectivity: application to the Barcelona Metropolitan Area, Landscape Urban Plan., 71, 243-262, 2005.

Midcontinent Ecological Science Center: PHABSIM for windows manual and exercise, US Geological Survey, USGS, 2001.

Morgan, R. P., Kline, K. M., and Cushman, S. F.: Relationships among nutrients, chloride and biological indices in urban Maryland streams, Urban Ecosyst., 10, 153-166, 2007.

Morrison, S. W.: The Percival Creek Corridor Plan, J. Soil Water Conserv., 43, 465-467, 1988.

Petts, G. E.: Water allocation to protect river ecosystems, Regul. River., 12, 353-365, 1996.
Phillips, J. D.: Nonpoint source pollution control effectiveness of riparian forests along a coastal plain river, J. Hydrol., 110, 221237, 1989.

Poff, N. L., Allan, J. D., Bain, M. B., Karr, J. R., Prestegaard, K. L., Richter, B. D., Sparks, R. E., and Stromberg, J. C.: The natural flow regime, Bioscience, 47, 769-784, 1997.

Quinn, J. M. and Hickey, C. W.: Characterization and classification of benthic invertebrate communities in 88 New Zealand rivers in relation to environmental factors, New Zeal. J. Mar. Fresh., 24, 387-409, 1990.

Richter, B., Baumgartner, J., Wigington, R., and Braun, D.: How much water does a river need? Freshwater Biol., 37, 231-249, 1997.

Schoonover, J. E., Williard, K. W. J., Zaczek, J. J., Mangun, J. C., and Carver, A. D.: Nutrient Attenuation in Agricultural Surface Runoff by Riparian Buffer Zones in Southern Illinois, USA, Agroforest. Syst., 64, 169-180, 2005.

Shang, S. H.: A multiple criteria decision-making approach to estimate minimum environmental flows based on wetted perimeter, River Res. Appl., 24, 54-67, 2008.

Smith, D. S. and Hellmund, P. C.: Ecology of greenways: Design and function of linear conservation areas, University of Minnesota Press, Mineapolis, 58-64, 1993.

Sweeney, B. W., Bott, T. L., Jackson, J. K., Kaplan, L. A., Newbold, J. D., Standley, L. J., Hession, W. C., and Horwitz, R. J.: Riparian deforestation, stream narrowing, and loss of stream ecosystem services, P. Natl. Acad. Sci. USA, 101, 14132-14137, 2004.

Thame, R.: A global perspective on environmental flow assessment: Emerging trends in the development and application of environmental flow methodologies, River Res. Appl., 19, 397-441, 2003.

Wang, L. Q. and Song, Q. B.: Study on the protection measures for the water source areas of Panjiakou and Daheiting Reservoirs, Haihe Water Resour., 4, 21-23, 2007 (in Chinese).

Wang, W., Yang, X. H., and Wang, Y. T.: Ecological water requirements in the lower reaches of the Luanhe River Basin, Adv. Water Sci., 20, 560-565, 2009 (in Chinese).

Ward, J. V. and Stanford, J. A.: The ecology of regulated streams, Plenum Press, New York, USA, 1979.

Wei, Y. C., Miao, H., Ouyang, Z. Y., and Wang, X. K.: Primary estimate of ecological water requirement in Haihe Basin, Acta Ecologica Sinica, 24, 2100-2107, 2004 (in Chinese).

Welsch, D. J.: Riparian Forest Buffers: function and design for protection and enhancement of water resources, NA-PR-07-91, USDA Forest Service, Radnor, PA, 1991.

Wu, Y. X., Wang, G. X., Wu, Y. N., Feng, H. L., Shen, F. X., Lei, S. H., and Shi, R.: Methods for river functional regionalization and a case study, Adv. Water Sci., 22, 741-749, 2011.

Xu, S. G., Shi, R. H., and Zhao, Q.: Research on the river function regionalization, Sci. China Ser. E, 52, 3030-3037, 2009.

Yu, R. H., Li, C. Y., Liu, T. X., and Xu, Y. P.: The environment evolution of Wuliangsuhai wetland, J. Geogr. Sci. 14, 456-464, 2004. 